\title{
Prevalence of nosocomial infections in Iran: A systematic review and meta-analysis
}

\author{
Ahmad Ghashghaee ${ }^{1}$, Masoud Behzadifar², Samad Azari², Zeynab Farhadi³, Nicola Luigi Bragazzi ${ }^{4}$, \\ Meysam Behzadifar ${ }^{5,6}$, Sahar Sadat Saeedi Shahri ${ }^{1}$, Mozhgan Sadat Ghaemmohamadi ${ }^{1}$, Faezeh Ebadi ${ }^{1}$, \\ Roghayeh Mohammadibakhsh7, Hesam Seyedin ${ }^{7}$, Mahya Razi Moghadam ${ }^{1}$
}

Received: 8 Feb 2018

Published: 11 June 2018

\begin{abstract}
Background: Nosocomial infections represent a serious public health concern worldwide, and, especially, in developing countries where, due to financial constraints, it is difficult to control infections. This study aimed to review and assess the prevalence of nosocomial infections in Iran.

Methods: Different databases were searched between January 2000 and December 2017. To determine the pooled prevalence, the stochastic DerSimonian-Laird model was used, computing the effect size with its $95 \%$ confidence interval. To examine the heterogeneity among studies, the I2 test were conducted. The reporting of observational studies in epidemiology (STROBE) checklist was used to assess the methodological quality of observational studies. To further investigate the source of heterogeneity, meta-regression analyses stratified by publication year, sample size and duration of hospitalization in the hospital were carried out.

Results: 52 studies were included. Based on the random-effects model, the overall prevalence of nosocomial infection in Iran was 4.5\% [95\% CI: 3.5 to 5.7] with a high, statistically significant heterogeneity (I2=99.82\%). A sensitivity analysis was performed to ensure the stability results. After removing each study, results did not change. A cumulative meta-analysis of the included studies was performed based on year of publication and the results did not change. In the present study, a high rate of infections caused by Klebsiella pneumoniae (urinary tract, respiratory tract, and bloodstream infections) was found.

Conclusion: Preventing and reducing hospital infections can significantly impact on reducing mortality and health-related costs. Implementing ad hoc programs, such as training healthcare staff on admission to the hospital, may play an important role in reducing infections spreading.
\end{abstract}

Keywords: Nosocomial infections, Prevalence, Iran, Systematic review, Meta-analysis, Hospital

Copyright@ Iran University of Medical Sciences

Cite this article as: Ghashghaee A, Behzadifar M, Azari S, Farhadi Z, Luigi Bragazzi N, Behzadifar M, Saeedi Shahri SS, Ghaemmohamadi MS, Ebadi F, Mohammadibakhsh R, Seyedin H, Razi Moghadam M. Prevalence of nosocomial infections in Iran: A systematic review and meta-analysis. Med J Islam Repub Iran. 2018(11 June);32:48. https://doi.org/10.14196/mjiri.32.48

\section{Introduction}

Nosocomial infections (NIs) represent a serious public health concern worldwide (1), and, especially, in developing countries where, due to financial constraints, it is difficult to control $(2,3)$. Increased prevalence of NIs in some cases leads to patient's arbitrary use of drugs, causing serious health hazards as well as other problems such

Corresponding author: Dr Masoud Behzadifar, masoudbehzadifar@gmail.com

1. Student Research Committee, Iran University of Medical Sciences, Tehran, Iran.

2. Health Management and Economics Research Center, Iran University of Medical

Sciences, Tehran, Iran.

3. Babol University of Medical Sciences, Babol, Iran.

4. School of Public Health, Department of Health Sciences (DISSAL), University of Genoa, Genoa, Italy.

5. Social Determinants of Health Research Center, Lorestan University of Medical Sciences, Khorramabad, Iran.

6. Department of Epidemiology, Faculty of Health \& Nutrition, Lorestan University of Medical Sciences, Khorramabad, Iran.

7. Department of Health Services Management, School of Health Management and Information Sciences, Iran University of Medical Sciences, Tehran, Iran. as drug resistance and death in patients (4). Worldwide, about $8.7 \%$ of hospitalized patients are at risk of exposure to NIs which considered as hospital-acquired infections and can complicate certain conditions such as cancer, organ transplant, and surgery, and also increasing mortality rate. As such, NIs generate a high societal burden, taking

$\uparrow$ What is "already known" in this topic:

Nosocomial infections (NIs) represent a serious public health concern worldwide. Increased prevalence of NIs in some cases leads to patient's arbitrary use of drugs, causing serious health hazards as well as significant problems such as drug resistance and death in patients.

\section{$\rightarrow$ What this article adds:}

This study aimed to inform and assess the prevalence of NIs in Iran using a meta-analytic approach. Based on the randomeffects model, the overall prevalence of NIs in Iran was $4.5 \%$. Proper training of healthcare staff in hospital, can play an important role in reducing NIs spreading in Iran. 
into account the costs for treatment, the increased length of hospital stay and the related mental and emotional stress (5).

Due to the wide variation of health-care systems in different countries, numerous reports have reported varying nosocomial infection rates $(6,7)$. The World Health Organization (WHO) carried out an epidemiological study conducted in 14 countries worldwide and found that the overall prevalence of NIs was $8.7 \%$ (ranging from $5.0 \%$ in North America and in Europe to $40.0 \%$ in Asia, Latin America, and Sub-Saharan Africa) (7). The knowledge of the epidemiology of NIs is crucial in establishing programs for controlling this acquired infection in hospitals, implementing effective and reliable plans (8).

Iran represents one of the developing countries, which faces with the issue of NIs imposing a high economic onus, in terms of high costs annually for the Ministry of Health $(\mathrm{MoH})$ and private hospital managers. Several studies have been performed in different parts of the country related to the epidemiology of nosocomial infections. These studies can be valuable for healthcare workers and managers in developing an effective control program. This study aimed to review and assess the prevalence of NIs in Iran using a meta-analytic approach.

\section{Methods \\ Literature search}

The results and their analysis in this study were reported according to the PRISMA guidelines (Appendix 1) (9). Embase, PubMed/MEDLINE via Ovid, Web of Science, Scopus and Google Scholar as well as national Iranian databases, including SID, Magiran, and Irandoc, with medical subject headings (MeSH) terms and a proper use of keywords. The search strategy was as follows: (Nosocomial Infections OR Hospital Infections OR Healthcare Associated Infections OR Cross Infections) AND Iran. Articles written in Farsi and English were searched and a time filter (between January 2000 and December 2017) applied. Reference lists of articles as well as national and international conferences related to the topic were also searched.

\section{Inclusion and exclusion criteria}

Inclusion criteria were: 1) population-based observational studies reporting the prevalence of NIs, 2) crosssectional, retrospective and case-control studies, and 3) pertinent studies with clear and detailed data. Case reports, case series, letters to editor, editorials, commentaries, reviews and clinical trials as well as studies not calculating the prevalence of NIs, as well as studies not calculating the prevalence of NIs were excluded.

\section{Data extraction}

From included papers, two authors independently extracted following data: first author, year of publication, sample size, number of positive cases detected, age, region, the geography of the study, study design, and prevalence rate. Disagreement between them was solved through discussion or including a third person as a judge.

\section{Quality of studies}

To check the methodological quality of included studies, the strengthening the reporting of observational studies in epidemiology (STROBE) checklist was used (10), categorizing the studies into three groups of high, medium and low quality.

\section{Statistical analysis}

To determine the pooled prevalence, the stochastic DerSimonian-Laird model was used, computing the effect size with its $95 \%$ confidence interval (CI) and pictorially representing it with a Forest plot. To examine the heterogeneity among studies, the $\mathrm{I}^{2}$ test were conducted (11). To further investigate the source of heterogeneity, metaregression analyses stratified by publication year, sample size and duration of hospitalization in the hospital were carried out. The sensitivity analysis was performed to ensure the stability and robustness of results. Subgroup analyses were performed based on study quality, geographic areas, sample size, year of publication, type of infection, and hospital wards. The cumulative meta-analysis was performed based on year of publication. Egger's test for publication bias was carried out (12). All analyses were performed using the commercial software Comprehensive Meta-Analysis Ver.2 (Biostat, NJ, USA). All figures with $\mathrm{p}<0.05$ were considered statistically significant.

\section{Results}

\section{Selected studies}

Finally, after an initial search, removing duplicates and checking the title and abstract of studies, 52 studies were selected based on inclusion and exclusion criteria (13-64). Fig. 1 shows the process of finding and selecting studies.

The total sample size consisted of $8,989,980$ subjects. Table 1 shows the main characteristics of the included studies.

The overall prevalence of nosocomial infections in Iran

Based on the random-effects model, the overall prevalence of NIs in Iran was $4.5 \%$ [95\% CI: 3.5 to 5.7] with a high, statistically significant heterogeneity $\left(\mathrm{I}^{2}=99.82\right)$. Fig. 2 shows the overall prevalence.

\section{Sensitivity analysis}

A sensitivity analysis was performed to ensure the stability results. After removing each study, results did not change. Appendix 2 shows the sensitivity analysis.

\section{Cumulative meta-analysis}

A cumulative meta-analysis of the included studies was performed based on year of publication and the results did not change. Appendix 3 shows the cumulative metaanalysis.

\section{Sub-group analysis}

Table 2 shows the results of the different sub-group analyses according to the quality of studies, geographic regions, sample size, year of publication, type of infection, and hospital wards. 


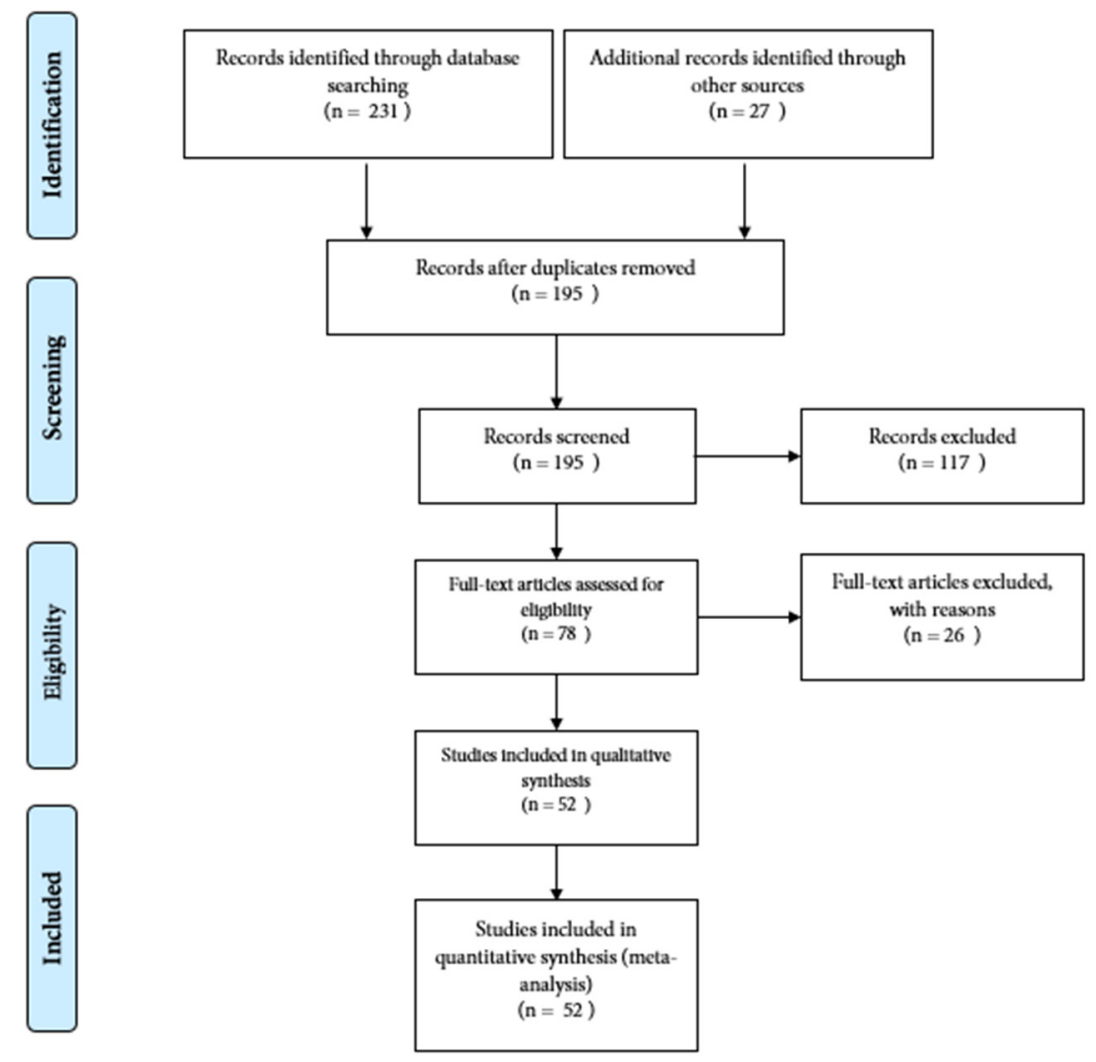

Fig. 1. Flowchart of the present systematic review and meta-analysis

\section{Meta-regression}

Table 3 shows the results of the meta-regression analysis.
Publication bias

Egger's test was carried out to assess publication bias (Fig. 3). An evidence of publication bias was found $(\mathrm{p}=0.00)$

Table 1. The main characteristics studies included

\begin{tabular}{|c|c|c|c|c|c|c|c|c|}
\hline First Author & Year & Sample & $\begin{array}{c}\text { Average Length } \\
\text { of Stay }\end{array}$ & Common infection & Place & Common Bacteria & Hospital unit & $\begin{array}{l}\text { Quality } \\
\text { study }\end{array}$ \\
\hline Hajibagheri & 2003 & 160 & 16 & Pneumonia & Sanandaj & Klebsiella pneumoniae & NA & High \\
\hline Askarian & 2003 & 170 & 19 & wound infection & Shiraz & NA & NA & High \\
\hline Askarian & 2003 & 1483 & 7 & Surgical Site Infection & Shiraz & NA & Surgery department & low \\
\hline Sadeghzadeh & 2005 & 150 & NA & Urinary tract infection & Zanjan & Escherichia coli & ICU & High \\
\hline Soltani Arabshahi & 2005 & 810 & 17 & Surgical Site Infection & Tehran & NA & Surgery department & Medium \\
\hline Rahbar & 2005 & 6492 & NA & Bloodstream infections & Orumieh & Staphylococcus & Neonatal ward & Medium \\
\hline Sadeghifard & 2006 & 5572 & NA & Urinary tract infection & Elam & Escherichia coli & Surgery department & Medium \\
\hline Ekrami & 2007 & 182 & NA & wound infection & Ahvaz & Pseudomonas & NA & Medium \\
\hline Ghazvini & 2008 & 971 & 12 & Bloodstream infections & Mashhad & Staphylococcus & NICU & Medium \\
\hline Lahsaeizadeh & 2008 & 2667 & NA & Surgical Site Infection & Shiraz & NA & Surgery department & High \\
\hline Ghorban Alizadegan & 2008 & 3974 & 2 & Respiratory Infection & Tehran & Staphylococcus & ICU & Medium \\
\hline Hassanzadeh & 2009 & 89 & 16 & Urinary tract infection & Shiraz & Pseudomonas & ICU & High \\
\hline Asl & 2009 & 102 & 17 & Pneumonia & Tehran & Staphylococcus & PICU & Medium \\
\hline Mohammadimehr & 2009 & 165 & 20 & Pneumonia & Tehran & Klebsiella pneumoniae & NA & Medium \\
\hline Amini & 2009 & 691 & 27 & Respiratory Infection & Tehran & Acinetobacter & $\mathrm{ICU}$ & Medium \\
\hline Sohrabi & 2009 & 23816 & NA & Urinary tract infection & Shahrod & Escherichia coli & ICU & Medium \\
\hline Darvishpour & 2010 & 270 & NA & NA & NA & Enterobacter & ICU & High \\
\hline Aletayyeb & 2010 & 1604 & 16 & Pneumonia & Ahvaz & Klebsiella pneumoniae & Neonatal ward & Medium \\
\hline Nadi & 2011 & 353 & 4 & Pneumonia & Hamadan & Klebsiella pneumoniae & ICU & Medium \\
\hline Tabatabaei & 2011 & 428 & 23 & Urinary tract infection & Tehran & Escherichia coli & PICU & High \\
\hline Amini & 2011 & 691 & NA & Pneumonia & Tehran & Acinetobacter & ICU & Medium \\
\hline Ghorbani & 2011 & 772 & NA & Urinary tract infection & Ahvaz & Pseudomonas & $\mathrm{ICU}$ & Medium \\
\hline Askarian & 2011 & 4013 & NA & Urinary tract infection & Shiraz & NA & NA & Medium \\
\hline Larypoor & 2011 & 21054 & NA & Urinary tract infection & Qom & Escherichia coli & ICU & low \\
\hline Masoumi Asl & 2011 & 6616520 & NA & Urinary tract infection & NA & Pseudomonas & NA & Medium \\
\hline Mobaien & 2012 & 353 & NA & Urinary tract infection & Hamadan & Staphylococcus & ICU & High \\
\hline Soltani & 2012 & 464 & NA & Bloodstream infections & Tehran & Staphylococcus & ICU & Medium \\
\hline Alaghehbandan & 2012 & 677 & 21 & NA & Tehran & Pseudomonas & NA & High \\
\hline Pourakbari & 2012 & 1497 & 8 & Respiratory Infection & Tehran & Staphylococcus & Children's section & low \\
\hline Barak & 2012 & 3254 & 27 & Sepsis & Ardabil & Klebsiella pneumoniae & NICU & Medium \\
\hline Riahin & 2012 & 3400 & NA & Surgical Site Infection & Qom & Staphylococcus & Surgery department & Medium \\
\hline
\end{tabular}


Prevalence of nosocomial infections in Iran

\begin{tabular}{|c|c|c|c|c|c|c|c|c|}
\hline \multicolumn{9}{|l|}{ Table 1. Cntd } \\
\hline Askarian & 2012 & 3450 & NA & Bloodstream infections & Shiraz & NA & Surgery department & Medium \\
\hline Assar & 2012 & 9407 & NA & Urinary tract infection & Ahvaz & Enterobacter & ICU & Medium \\
\hline Zahraei & 2012 & 1879356 & NA & Urinary tract infection & NA & NA & ICU & low \\
\hline Askarian & 2013 & 4013 & NA & Urinary tract infection & Shiraz & NA & NA & low \\
\hline Abdoli Oskouie & 2013 & 7744 & 4 & Urinary tract infection & Tabriz & Staphylococcus & NICU & Medium \\
\hline Akbari & 2013 & 25776 & 22 & Respiratory Infection & Orumieh & Escherichia coli & ICU & High \\
\hline Masoumi Asl & 2013 & 47380 & NA & Urinary tract infection & NA & Escherichia coli & Burn unit & low \\
\hline Hamedi & 2014 & 811 & NA & Urinary tract infection & Mashhad & Pseudomonas & PICU & low \\
\hline Hoseini & 2014 & 3129 & 10 & Pneumonia & Tabriz & Staphylococcus & NICU & High \\
\hline Behzadnia & 2014 & 34556 & NA & wound infection & Mazandaran & Pseudomonas & NA & Medium \\
\hline Davoudi & 2014 & 57122 & 8 & wound infection & Mazandaran & Pseudomonas & Burn unit & low \\
\hline Shakib & 2015 & 750 & 2 & NA & Sanandaj & Klebsiella pneumoniae & ICU & low \\
\hline Basiri & 2015 & 1000 & 13 & Bloodstream infections & Hamadan & Escherichia coli & $\mathrm{NICU}$ & Medium \\
\hline Shojaei & 2015 & 12221 & NA & Surgical Site Infection & Qom & Pseudomonas & ICU & low \\
\hline Lavakhamseh & 2015 & 32400 & NA & Urinary tract infection & Sanandaj & Escherichia coli & Woman's ward & Medium \\
\hline Salmanzadeh & 2015 & 15779 & NA & Surgical Site Infection & Ahvaz & Staphylococcus & ICU & low \\
\hline Bijari & 2015 & 36222 & NA & Pneumonia & NA & Klebsiella pneumoniae & $\mathrm{ICU}$ & low \\
\hline Tabatabaei & 2015 & 16140 & NA & Respiratory Infection & Zahedan & Acinetobacter & $\mathrm{ICU}$ & High \\
\hline Lavakhamseh & 2015 & 32400 & NA & Urinary tract infection & Sanandaj & E. coli & Woman's ward & Medium \\
\hline Darvishpoor & 2016 & 1300 & 2 & Surgical Site Infection & Torbat & NA & NA & low \\
\hline Kazemian & 2016 & 62601 & NA & Urinary tract infection & Ardabil & Escherichia coli & $\mathrm{ICU}$ & High \\
\hline Falahi & 2017 & 35979 & NA & Pneumonia & Mashhad & Acinetobacter & $\mathrm{ICU}$ & High \\
\hline
\end{tabular}

Discussion

This study was a comprehensive study on the prevalence of NIs in Iran using a systematic review and metaanalytic approach. The prevalence of NIs in Iran was found as $4.5 \%$ (95\% CI: 3.5-5.7). Hospital infection rates range between $3.5 \%$ and $12 \%$ in developed countries and between $5.7 \%$ and $19.1 \%$ in developing countries (7), calling for the urgent need of better allocating resources and implementing a program for controlling infections (65). Differences in NIs rates among countries may not

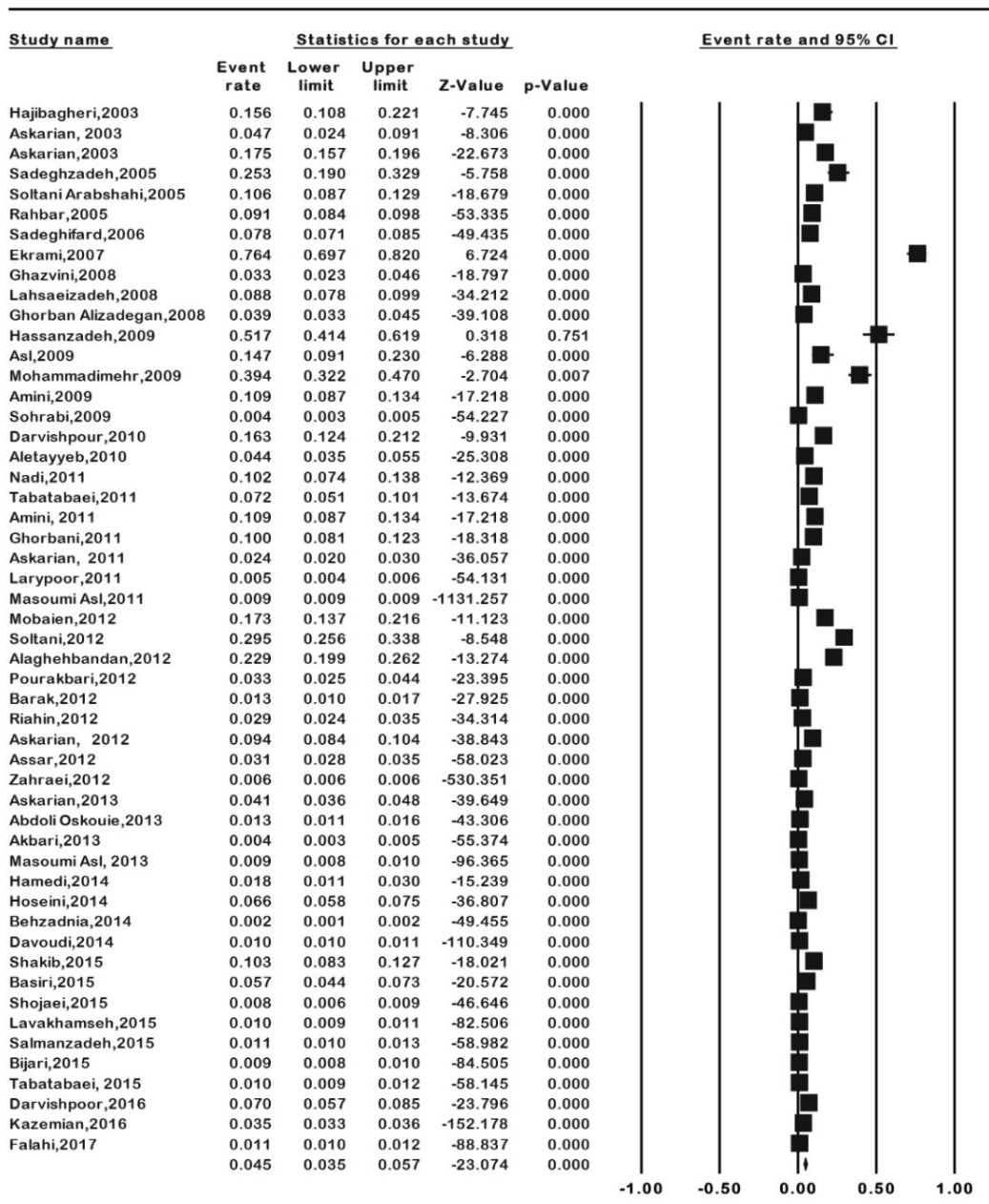

Fig. 2. The forest plot of the overall prevalence of nosocomial infections in Iran 
A. Ghashghaee, et al.

\begin{tabular}{|c|c|c|c|c|c|}
\hline Variables & No. studies & $\begin{array}{c}\text { Prevalence\% } \\
(95 \% \mathrm{CI})\end{array}$ & I2 (\%) & $\mathrm{p}$ & No. participants \\
\hline \multicolumn{6}{|l|}{ Quality of studies } \\
\hline High & 14 & $7.2 \%(4-12.6)$ & $99.54 \%$ & 0.0001 & 148589 \\
\hline Medium & 25 & $5.2 \%(2.9-9)$ & $99.82 \%$ & 0.0001 & 6762403 \\
\hline Low & 13 & $2 \%(1.1-3.6)$ & $99.75 \%$ & 0.0001 & 2078988 \\
\hline \multicolumn{6}{|l|}{ Regional } \\
\hline Center & 13 & $7.1 \%(3.2-15)$ & $99.43 \%$ & 0.0001 & 46174 \\
\hline East & 8 & $1.4(0.9-2.2)$ & $98.49 \%$ & 0.0001 & 147639 \\
\hline North & 2 & $0.4 \%(0.1-2.4)$ & $99.42 \%$ & 0.0001 & 91678 \\
\hline South & 12 & $8.8 \%(4.8-15.7)$ & $99.41 \%$ & 0.0001 & 43629 \\
\hline West & 13 & $5.7 \%(3.6-8.8)$ & $99.34 \%$ & 0.0001 & 117334 \\
\hline Several regional & 4 & $1.5 \%(1.1-2.1)$ & $99.85 \%$ & 0.0001 & 8543526 \\
\hline \multicolumn{6}{|l|}{ Sample size } \\
\hline$\leq 1500$ & 24 & $13.3 \%(9.6-18.2)$ & $97.79 \%$ & 0.0001 & 14339 \\
\hline$>1500$ & 28 & $17 \%(13-22)$ & $99.84 \%$ & 0.0001 & 8975641 \\
\hline \multicolumn{6}{|l|}{ Year of publication } \\
\hline $2000-2005$ & 6 & $12.8 \%(8.8-18.2)$ & $96.00 \%$ & 0.0001 & 9265 \\
\hline $2006-2011$ & 19 & $7.6 \%(3.7-14.8)$ & $99.78 \%$ & 0.0001 & 6683934 \\
\hline $2012-2017$ & 27 & $2.4 \%(1.6-3.8)$ & $99.82 \%$ & 0.0001 & 2296781 \\
\hline \multicolumn{6}{|l|}{ Common infections } \\
\hline Wound & 4 & $4 \%(3-3.6)$ & $99.76 \%$ & 0.0001 & 92030 \\
\hline Bloodstream & 5 & $9 \%(5.4-14.6)$ & $98.33 \%$ & 0.0001 & 12377 \\
\hline NA & 3 & $15.8 \%(9.2-25.9)$ & $94.99 \%$ & 0.0001 & 1697 \\
\hline Pneumonia & 9 & $7.1 \%(3-15.6)$ & $99.50 \%$ & 0.0001 & 78405 \\
\hline Respiratory & 5 & $2.3 \%(0.8-6.6)$ & $99.38 \%$ & 0.0001 & 48078 \\
\hline Sepsis & 1 & $1.3 \%(1-7)$ & - & - & 3254 \\
\hline Surgical site & 7 & $4.4 \%(1.7-10.9)$ & $99.55 \%$ & 0.0001 & 37660 \\
\hline Urinary tract & 18 & $3.1 \%(2.3-4.2)$ & $99.85 \%$ & 0.0001 & 8716479 \\
\hline \multicolumn{6}{|c|}{ Common infection in hospital units } \\
\hline Burn unit & 2 & $1 \%(0.8-1.1)$ & $82.49 \%$ & 0.0001 & 104502 \\
\hline Children's section & 1 & $3.3 \%(2.5-4.4)$ & - & - & 1497 \\
\hline ICU & 22 & $3.9 \%(2.3-6.5)$ & $99.83 \%$ & 0.0001 & 2146908 \\
\hline Others & 10 & $7.1 \%(2.3-20.3)$ & $99.80 \%$ & 0.0001 & 6661756 \\
\hline Neonatal & 2 & $6.4 \%(3.1-12.7)$ & $97.19 \%$ & 0.0001 & 8096 \\
\hline NICU & 5 & $2.9 \%(1.3-6.3)$ & $98.36 \%$ & 0.0001 & 16098 \\
\hline PICU & 3 & $5.9 \%(2-16.6)$ & $94.39 \%$ & 0.0001 & 1341 \\
\hline Surgery department & 6 & $8.5 \%(5.8-12.4)$ & $98.19 \%$ & 0.0001 & 17382 \\
\hline Woman's ward & 1 & $1(0.9-1.1)$ & - & - & 32400 \\
\hline \multicolumn{6}{|l|}{ Common bacteria } \\
\hline Klebsiella pneumonia & 7 & $6.6 \%(2.1-19.6)$ & $99.46 \%$ & 0.0001 & 42508 \\
\hline Escherichia coli & 10 & $2.2 \%(1.1-4.2)$ & $99.67 \%$ & 0.0001 & 220177 \\
\hline Staphylococci & 11 & $5.4 \%(2.9-9.8)$ & $99.29 \%$ & 0.0001 & 43905 \\
\hline Pseudomonas & 9 & $4.9 \%(2-11.3)$ & $99.78 \%$ & 0.0001 & 6722950 \\
\hline Acinetobacter & 4 & $3.5 \%(1-10.8)$ & $99.52 \%$ & 0.0001 & 53501 \\
\hline Enterobacter & 2 & $7.3 \%(1.3-31.4)$ & $99.04 \%$ & 0.0001 & 9677 \\
\hline Other infections & 9 & $5.3 \%(1.5-16.9)$ & $99.90 \%$ & 0.0001 & 1897262 \\
\hline \multicolumn{6}{|l|}{ Gram bacteria } \\
\hline Positive & 10 & $5.1 \%(2.5-10.2)$ & $99.23 \%$ & 0.0001 & 37413 \\
\hline Negative & 32 & $4 \%(2.8-5.7)$ & $99.77 \%$ & 0.0001 & 7048813 \\
\hline $\mathrm{NA}$ & 10 & $5.6 \%(1.7-16.7)$ & 99.92 & 0.0001 & 1903754 \\
\hline Moderator & No studies & No. participants & Coefficient & Z-value & $\mathrm{p}$ \\
\hline Year of publication & 52 & $8,989,980$ & -0.06 & -24.51 & 0.00 \\
\hline Sample size of studies & 52 & $8,989,980$ & -0.00 & -67.90 & 0.00 \\
\hline Average length of stay & 23 & 113,249 & 0.02 & 9.23 & 0.00 \\
\hline
\end{tabular}

only reflect a socio-economical feature of each country but also depend on criteria and diagnostic tests used to detect infections, as well as on the different reporting systems and their quality (66).

We found that bloodstream infections, surgical site infections, and pneumonia were the most common NIs observed (67). Hospital-acquired pneumonia is directly related to air conditioning systems. In many developing countries due to lack of proper facilities, the installed ventilation systems may increase pneumonia rate (68). Studies have shown that surgical infection rates vary between $10 \%$ and $20 \%$, and are mainly due to Staphylococcus au-

reus (69). In cases of complications, wound healing is delayed, the possibility of further surgery increases, and patients have to be treated with antibiotics. This increases the length of hospital stay and the health-related expenditure (70).

In our study, most infections occurred in the surgical ward. A study carried out in America reported a 2-5\% rate (71), while a meta-analysis of surgical infection rate estimated a pooled prevalence of $3.7 \%$ (72). Surgical infections are particularly challenging (73). Identifying patients who are prone to such infections could minimize the incidence of nosocomial infections and reduce their burden in 


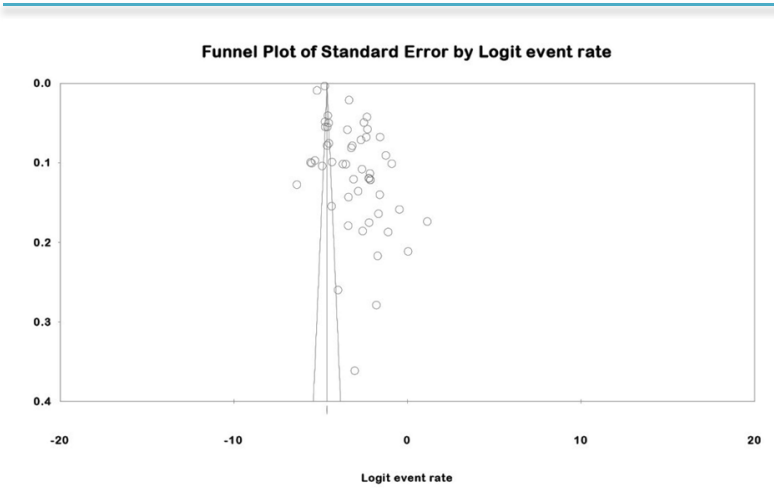

\section{Fig. 3. The Egger test for publication bias}

terms of deaths (71).

Further, our study computed a higher effect-size of infections caused by Gram-positive bacteria. A study computed a prevalence of these infections of about 5\% (3). Similar results were found by other scholars $(74,75)$. In the ICU, a significant amount of infections are due to Gram-positive bacteria, and this trend is increasing (76).

In the present study, a high rate of infections caused by Klebsiella pneumoniae (urinary tract, respiratory tract , and bloodstream infections) was found (77). This is particularly alarming in that the organism can become resistant to Carbapenem, which leads to increased use of Colistin, absorbing higher costs (78). Moreover, our study showed a strong correlation between length of stay in the hospital and hospital infections rate, in agreement with other studies (79-81). Based on geographical regions of Iran, the south of the country reported the highest incidence of NIs $(8.8 \%)$, due to weather conditions, being warm and dry, with high air temperature and humidity. The prevalence of NIs can vary according to the specific month of the year (82).

Meta-regression analysis based on year of publication showed a significant decreasing trend over the years, which may be due to the recent implementation of health promotion programs (83). Despite some strengths (including the systematic approach, and the robustness of findings as proven by the meta-regressions and by the subgroup, cumulative, and sensitivity analyses), some limitations of this study should be properly recognized. First, the heterogeneity was significantly high. This could reflect methodological differences among studies. Moreover, insufficient information was available to stratify the prevalence by gender. Further, in some provinces of Iran, epidemiological studies related to the prevalence of NIs were missing and, therefore, urgently needed.

\section{Conclusion}

The prevalence of NIs in Iran was determined as $4.5 \%$. Preventing and reducing hospital infections can significantly impact on reducing mortality and health-related costs tor. Implementing ad hoc programs, such as training healthcare staff in hospital, can play an important role in reducing spread of infections. The use of appropriate and advanced features for secure hospital environment is a major contribution to the decrease of NIs. Health policymakers in Iran can help reduce hospital infections by im- plementing appropriate policies, such as educational programs and improving the quality of surveillance system.

\section{Funding}

Iran University of Medical Sciences, Tehran, Iran (Grant No: 95-04-193-29990)

\section{Conflict of Interests}

The authors declare that they have no competing interests.

\section{References}

1. Khazaei S, Khazaei S, Ayubi E . Importance of prevention and control of Importance of Prevention and Control of Nosocomial Infections in Iran. Iran J Public Health. 2018;47(2):307-308

2. Allegranzi B, Bagheri Nejad S, Combescure C, Graafmans W, Attar $\mathrm{H}$, Donaldson L, et al. Burden of endemic health-care-associated infection in developing countries: systematic review and metaanalysis. Lancet. 2011;377(9761):228-41

3. Ahoyo TA, Bankolé HS, Adéoti FM, Gbohoun AA, Assavèdo S, Amoussou-Guénou M, et al. Prevalence of nosocomial infections and anti-infective therapy in Benin: results of the first nationwide survey in 2012. Antimicrob Resist Infect Control. 2014;3(17).

4. Behnke M, Hansen S, Leistner R, Peña Diaz LA, Gropmann A, Sohr D, et al. Nosocomial Infection and Antibiotic Use: A Second National Prevalence Study in Germany. Dtsch Arztebl Int. 2013;11(38):62733.

5. Becerra MR, Tantaleán JA, Suárez VJ, Alvarado MC, Candela JL, Urcia FC. Epidemiologic surveillance of nosocomial infections in a Pediatric Intensive Care Unit of a developing country. BMC Pediatr. 2010;10(66)

6. Ahoyo TA, Baba-Moussa F, Adeoti MF, Attolou G, Boco M, Kotchoni S, et al. Serratia marcescens outbreak on a general pediatric ward in Benin. J Pharm Biomed Sci. 2012;3:35-9.

7. Bagheri Nejad S, Allegranzi B, Syed SB, Ellis B, Pittet D. Healthcare-associated infection in Africa: a systematic review. Bull World Health Organ. 2011;89(10):757-65

8. Lyytikäinen O, Kanerva M, Agthe N, Möttönen T, Ruutu P, Finnish Prevalence Survey Study Group. Healthcare-associated infections in Finnish acute care hospitals: a national prevalence survey, 2005. J Hosp Infect. 2008;69(3):288-94.

9. Liberati A, Altman DG, Tetzlaff J, Mulrow C, Gotzsche PC, Ioannidis JP, et al. The PRISMA statement for reporting systematic reviews and meta-analyses of studies that evaluate healthcare interventions: explanation and elaboration. BMJ. 2009;339:b2700.

10.von Elm E, Altman DG, Egger M, Pocock SJ, Gotzsche PC, Vandenbroucke JP, et al. The Strengthening the Reporting of Observational Studies in Epidemiology (STROBE) statement: guidelines for reporting observational studies. Bull World Health Organ. 2007;85(11):867-72.

11.Aryankhesal A, Behzadifar M, Luigi Bragazzi N, Ghashghaee A, Behzadifar M. A A Framework for Conducting Meta-analysis Studies; Methodological Concerns and Recommendations. Iran J Public Health. $2018 ; 47(5): 773-774$.

12.Kicinski M. Publication Bias in Recent Meta-Analyses. Plos One. 2013;8(11):e81823.

13.Askarian M, Gooran NR. National Nosocomial Infection Surveillance System-based study in Iran: Additional hospital stay attributable to nosocomial infections. Am J Infect Control 2003;31(8):465-8

14.Askarian M, Hosseini RS, Kheirandish P, Memish ZA. Incidence of urinary tract and bloodstream infections in Ghotbeddin Burn Center, Shiraz 2000-2001. Burns. 2003;29(5):455-9.

15. Hajibagheri K, Afrasiabian S. An epidemiologic study of nosocomial infections and its related factors at the intensive care unit of Tohid Hospital, in Sanandaj during 2003-2004. SJKU. 2003;10(4).

16.Rahbar M, Gra-Agaji R, Hashemi S. Nosocomial blood stream infections in Imam Khomeini Hospital, Urmia Islamic Republic of Iran, 1999-2001. East Mediterr Health J. 2005;11(3):478-84.

17.Sadeghzadeh V, Hassani N. The Frequency Rate of Nosocomial Urinary Tract Infection in Intensive Care unit Patients in Shafiieh Hospital, Zanjan, 2004. ZUMS J. 2005;13(50). 
18.Soltani Arabshahi S, Haji Nasrollah E, Beyhaghi A. A survey on the risk factors of surgical wound infection. RJMS. 2005;12(46):313-21.

19.Sadeghifard N, Azizi Jalilian F, Zaeimi Yazdi J. A long-period survey on nosocomial infections in Ilam University Hospitals, Iran. Pak J Biol Sci. 2006;9(3):534-9.

20.Ekrami A, Kalantar E. Bacterial infections in burn patients at a burn hospital in Iran. Indian J Med Res. 2007;126(6):541-4.

21.Ghazvini K, Rashed T, Boskabadi H, Yazdan Panah M, Khakzadan $\mathrm{F}$, Safaee H, et al. Neonatal intensive care unit nosocomial bacterial infections. Tehran Univ Med J. 2008;66(5):349-54.

22.Ghorban Alizadegan M, Ranjbar R, Joneydi JN, Esfahani A, Esmaeili D, Goudarzi Z. A Study on the Prevalence of Nosocomial Infections in ICU Patients Admitted at Baqyiatallah Hospital. SJIMU. $2008 ; 16(1)$.

23.Lahsaeizadeh S, Jafari H, Askarian M. Healthcare-associated infection in Shiraz, Iran 2004-2005. J Hosp Infect. 2008;69(3):283-7.

24.Amini M, Sanjary L, Vasei M, Alavi S. Frequency evaluation of the nosocomial infections and related factors in Mostafa Khomeini Hospital" ICU" based on" NNI" system. JAUMS. 2009;7(1):9-14.

25.Asl HM, Nateghian A. Epidemiology of nosocomial infections in a pediatric intensive care unit (PICU). IJCID. 2009;4(2):83-6.

26.Hassanzadeh P, Motamedifar M, Hadi N. Prevalent bacterial infections in intensive care units of Shiraz University of Medical Sciences Teaching Hospitals, Shiraz, Iran. Jpn J Infect Dis. 2009;62(4):249-53

27.Mohammadimehr M, Feizabadi MM, Bahadori O, Khosravi M. Study of prevalence of gram-negative bacteria caused nosocomial infections in ICU in Besat hospital in Tehran and detection of their antibiotic resistance pattern-year 2007. Iran J Med Microbiol.2009;3(2):47-54.

28.Sohrabi MB, Khosravi A, Zolfaghari P, Sarrafha J. Evaluation of nosocomial infections in Imam Hossein (as) Hospital of Shahrood, 2005. J Birjand Univ Med Sci. 2009;16(3):33-9.

29. Aletayyeb H, Mohammad S, Dehdashtian M, Vafajoo A. Causes of nosocomial bacteremias in neonatal intensive care unit of Imam Khomeini Hospital-Ahvaz. Scientific Medical Journal (AJUMS). 2010;8(4):415-21.

30.Darvishpour A, Hashemian H, Faal E, Fasihi M. Survey of nosocomial infection and accompanied factors in neonatal intensive care unit. J Guilan Uni Med Sci. 2010;19(73):37.

31.Amini M, Sanjari L, Jalalinadoushan M. Frequency and related factors of nosocomial infections in ICU of tertiary hospital in Tehran, Iran, according to NNIS. IJID. 2011;15:S56.

32.Askarian M, Mahmoudi H, Assadian O. First report of Iranian National nosocomial infection surveillance system software. BMC Proceedings. 2011;5.

33. Ghorbani BA, Asadpoor S. Nosocomial infections in intensive care unit of Ahvaz Arya Hospital (2008-2009). Mod Care J. 2011;8(2).

34.Larypoor M, Frsad S. Evaluation of nosocomial infections in one of hospitals of Qom, 2008. Iran J Med Microbiol. 2011;5(3):7-17.

35.Masoumi Asl H. The National Nosocomial Infections Surveillance in Iran. A 4 years report. BMC Proceedings. 2011;5.

36.Nadi E, Nekouii B, Mobin A, Nekouii A, Moghim Beigi A. Frequency of Nosocomial Pneumonia in ICUs of Hospitals of Hamadan University of Medical Sciences. JIMS. 2011;29(153).

37.Tabatabaei SA, Fahimzad A, Shirvani F, Naderi M, Talebian M. Prevalence of nosocomial urinary tract infection in PICU of referral children hospital in Iran. Pak J Med Sci. 2011;27(3):618-21.

38.Alaghehbandan R, Azimi L, Rastegar Lari A. Nosocomial infections among burn patients in Teheran, Iran: a decade later. Ann Burns Fire Disasters. 2012;25(1):3-7.

39.Askarian M, Yadollahi M, Assadian O. Point prevalence and risk factors of hospital acquired infections in a cluster of universityaffiliated hospitals in Shiraz, Iran. J Infect Public Health. 2012;5(2):169-76.

40.Assar S, Akhoundzadeh R, Aleali AM, Latifi SM, Salemzadeh M Survey of nosocomial infections and causative bacteria: A hospitalbased study. Pak J Med Sci. 2012;28(3).

41.Barak M, Pourfarzi F, Jirodi S, Rahimi G, Pahlavan Y. Etiology and clinical investigation of nosocomial infections at Ardabil bou-ali hospital during 2010. J Ardabil Univ Med Sci. 2012;12(5):33-9.

42.Mobaien A, Amirhasani S, Nekoei A, Nekoei B. Study of Nosocomial Urinary Tract Infections in the ICUs of Hamadan Besat and Ekbatan Hospitals during the 1387-89 Period. ZUMS J. 2012;20(79):94-102.
43.Pourakbari B, Rezaizadeh G, Mahmoudi S, Mamishi S. Epidemiology of nosocomial infections in pediatric patients in an Iranian referral hospital. J Prev Med Hyg. 2012;53(4):204-6.

44.Riahin A. Frequency of surgical wound infection in operated patients at Golpayegani Hospital in Qom (2008-2009). J QUMS 2012;15(4):95-100.

45.Soltani R, Khalili H, Abdollahi A, Rasoolinejad M, Dashti-Khavidaki S. Nosocomial Gram-positive antimicrobial susceptibility pattern at a referral teaching hospital in Tehran, Iran. Future Microbiol. 2012;7(7):903-10

46.Zahraei SM, Eshrati B, Masoumi Asl H, Pezeshki Z. Epidemiology of four main nosocomial infections in Iran during March 2007 . March 2008 based on the findings of a routine surveillance system. Arch Iran Med. 2012;15(12):764-6.

47.Abdoli Oskouie S, Ahangarzadeh Rezaee M, Ghabili K, Firoozi F. An Epidemiological study of nosocomial infections in Tabriz children's hospital based on national nosocomial infection surveillance system (NNIS). Life Sci J. 2013;10(1):277-9.

48.Akbari M, Nejad Rahim R, Azimpour A, Bernousi I, Ghahremanlu H. A survey of nosocomial infections in intensive care units in an imam Reza hospital to provide appropriate preventive guides based on international standards. J Urmia Univ Med Sci. 2013;23(6):591-6.

49.Askarian M, Mahmoudi H, Assadian O. Incidence of Nosocomial Infections in a Big University Affiliated Hospital in Shiraz, Iran: A Six-month Experience. Int J Prevent Med. 2013;4(3):366-72.

50.Masoumi Asl H. National nosocomial infection surveillance report in Iran in 2012. Antimicrob Resist Infect Cont. 2013;2.

51.Behzadnia S, Davoudi A, Rezai MS, Ahangarkani F. Nosocomial infections in pediatric population and antibiotic resistance of the causative organisms in north of iran. Iran Red Crescent Med J. 2014;16(2):e14562.

52.Davoudi AR, Najafi N, Shirazi MH, Ahangarkani F. Frequency of bacterial agents isolated from patients with nosocomial infection in teaching hospitals of Mazandaran University of medical sciences in 2012. Caspian J Intern Med. 2014;5(4):227-31.

53.Hamedi AK, Amirian MH, Kouzegaran S. Nosocomial infections and antibiotic administration in pediatric department, imam reza hospital, Mashhad-Iran. Int J Pediatr. 2014;2(2):157-61.

54.Hoseini MB, Abdinia B, Rezaee MA, Oskouie SA. The study of nosocomial infections in neonatal intensive care unit: A prospective study in northwest Iran. Int J Pediatr. 2014;2(3):25-33.

55.Shakib P, Lavakhamseh H, Mohammadi B. The prevalence of nosocomial infection in ICU, Besat Hospital, Sanandaj City, Iran. Zanko J Med Sci. 2014;15(45):36-41.

56.Basiri B, Sabzehei MK, Shokouhi M, Moradi A. Evaluating the incidence and risk factors of nosocomial infection in neonates hospitalized in the neonatal intensive care unit of fatemieh hospital in Hamadan, Iran, 2012 - 2013. Arch Pediatr Infect Dis. 2015;3(2).

57.Bijari B, Abbasi A, Hemati M, Karabi K. Nosocomial infections and related factors in southern khorasan hospitals. Iran J Med Microbiol. 2015;8(4):69-73.

58.Lavakhamseh H, Shakib P, Rouhi S, Mohammadi B, Ramazanzadeh R. A survey on the prevalence and antibiotic sensitivity of nosocomial infections in the besat hospital, Sanandaj, Iran. J NI. 2015;1(2).

59.Salmanzadeh S, Yousefi F, Ahmadi F, Geravandi S, Moien M, Mohammadi MJ, et al. Evaluation of nosocomial infections in a teaching hospital. Avicenna J Clin Microb Infec. 2015;2(3).

60.Shojaei S, Rahimi T, Amini M, Shams S. Survey of Nosocomial Infections in Patients Admitted to Nekoei Hospital of Qom City in 2012, Iran. Qom Univ Med Sci J. 2015;9(4).

61.Tabatabaei SM, Behmanesh Pour F, Osmani S. Epidemiology of Hospital-Acquired Infections and Related Anti-Microbial Resistance Patterns in a Tertiary-Care Teaching Hospital in Zahedan, Southeast Iran. Int J Infect. 2015;2(4):e29079.

62.Darvishpoor K, Rezaei Manesh MR. Prevalence of nosocomial infections and microbial causes in Torbat heydariyeh 9dey educational and clinical hospital in 2012 and 2013. Iran J Med Microbiol. 2016;10(1):93-6.

63.Kazemian H, Pourmand MR, Pourramezan N, Jamshidi Y, Modares Sadrani SN, Hosseini SM, et al. Evaluation of healthcare-associated infections in Ardabil hospitals, Iran, 2014-2015. Res J Pharm Biol Chem Sci. 2016;7(5):898-903

64.Falahi J, Khaledi A, Alikhani MY, Taghipour A, Jamehdar SA, Honarmand $\mathrm{M}$, et al. Prevalence of Nosocomial Infection in DifferentWards of Ghaem Hospital, Mashhad. Avicenna J Clin 
Microb Infec. 2017; In Press(In Press):e40297.

65. World health organization. Environment and health in developing countries 2017 [Available from: http://www.who.int/ heli/risks/ehindevcoun/en/.

66.Guggenbichler JP, Assadian O, Boeswald M, Kramer A. Incidence and clinical implication of nosocomial infections associated with implantable biomaterials - catheters, ventilator-associated pneumonia, urinary tract infections. GMS Krankenhaushy interdiszip. 2011;6(1):Doc18

67. World health organization. Preventing bloodstream infections from central line venous catheters 2016 [Available from: http://www.who.int/patientsafety/implementation/bsi/en/.

68.Craven DE, Hjalmarson KI. Ventilator-associated tracheobronchitis and pneumonia: thinking outside the box. Clin Infect Dis. 2010;51(Suppl 1):S59-66.

69.Leaper D, Ousey K. Evidence update on prevention of surgical site infection. Curr Opin Infect Dis. 2015;28(2):158-63.

70.Harrop JS, Styliaras JC, Ooi YC, Radcliff KE, Vaccaro AR, Wu C. Contributing factors to surgical site infections. J Am Acad Orthop Surg. 2012;20(2):94-101.

71.Anderson DJ, Kaye KS. Staphylococcal surgical site infections. Infect Dis Clin North Am. 2009;23(1):53-72.

72.Korol E, Johnston K, Waser N, Sifakis F, Jafri HS, Lo M, et al. A Systematic Review of Risk Factors Associated with Surgical Site Infections among Surgical Patients. PLoS One. 2013;8(12):e83743.

73. Puchter L, Chaberny IF, Schwab F, Vonberg R-P, Bange F-C, Ebadi E. Economic burden of nosocomial infections caused by vancomycinresistant enterococci. Antimicrob Resist Infect Control. 2018;7:1.

74.Kritsotakis EI, Kontopidou F, Astrinaki E, Roumbelaki M, Ioannidou E, Gikas A. Prevalence, incidence burden, and clinical impact of healthcare-associated infections and antimicrobial resistance: a national prevalent cohort study in acute care hospitals in Greece. Infect Drug Resist. 2017;10:317-328.
75.Habibi S, Wig N, Agarwal S, Sharma SK, Lodha R, Pandey RM, et al. Epidemiology of nosocomial infections in medicine intensive care unit at a tertiary care hospital in northern India. Trop Doct. 2008;38(4):233-5.

76.Kohlenberg A, Schwab F, Geffers C, Behnke M, Rüden H, Gastmeier P. Time-trends for Gram-negative and multidrug-resistant Grampositive bacteria associated with nosocomial infections in German intensive care units between 2000 and 2005. Clin Microbiol Infect. 2008;14(1):93-6.

77.Rizvi MF, Hasan Y, Memon AR, Abdullah M, Rizvi MF, Saleem S, et al. Pattern of nosocomial infection in two intensive care units of a tertiary care hospital in Karachi. J Coll Physicians Surg Pak. 2007;17(3):136-9.

78.Nguyen KV, Thi Do NT, Chandna A, Nguyen TV, Pham CV, Doan PM, et al. Antibiotic use and resistance in emerging economies: a situation analysis for Viet Nam. BMC Public Health. 2013;13(1158).

79.Esteban J, Ortiz A, Fernández-Roblas R. Healthcare-associated infections: new challenges looking for answers. Clin Kidney J. 2015;8(1):100-101.

80.Dasgupta S, Das S, Chawan NS, Hazra A. Nosocomial infections in the intensive care unit: Incidence, risk factors, outcome and associated pathogens in a public tertiary teaching hospital of Eastern India. Indian J Crit Care Med. 2015;19(1):14-20.

81.Glance LG, Stone PW, Mukamel DB, Dick AW. Increases in mortality, length of stay, and cost associated with hospital-acquired infections in trauma patients. Arch Surg. 2011;146(7):794-801.

82. Chen $\mathrm{Y}, \mathrm{Xu} \mathrm{X}$, Liang J, Lin H. Relationship between climate conditions and nosocomial infection rates. Afr Health Sci. 2013;13(2):339-43.

83.Lankarani KB, Alavian SM, Peymani P. Health in the Islamic Republic of Iran, challenges and progresses. Med J Islam Repub Iran 2013;27(1):42-9.

Appendix 1. PRISMA checklist

$\begin{array}{lll}\text { Section/topic } & \text { Checklist item } & \text { Reported } \\ \text { on page \# }\end{array}$

TITLE: Prevalence of nosocomial infections in Iran: a systematic review and meta-analysis

Title

Abstract

Structured summary

Introduction

Rationale

Objectives

Methods

Protocol and registration

Eligibility criteria

Information sources

Search

Study selection

Data collection process

Data items

Risk of bias in individual studies

Summary measures

Synthesis of results
1 Identify the report as a systematic review, meta-analysis, or both.

Title

2 Provide a structured summary including, as applicable: background; objectives; data sources; study eligibility criteria, participants, and interventions; study appraisal and synthesis methods; results; limitations; conclusions and implications of key findings; systematic review registration number.

3 Describe the rationale for the review in the context of what is already known

4 Provide an explicit statement of questions being addressed with reference to participants, interventions, comparisons, outcomes, and study design (PICOS).

5 Indicate if a review protocol exists, if and where it can be accessed (e.g., Web address), and, if available, provide registration information including registration number.

6 Specify study characteristics (e.g., PICOS, length of follow-up) and report characteristics (e.g., years considered, language, publication status) used as criteria for eligibility, giving rationale.

7 Describe all information sources (e.g., databases with dates of coverage, contact with study authors to identify additional studies) in the search and date last searched.

8 Present full electronic search strategy for at least one database, including any limits used, such that it could be repeated.

9 State the process for selecting studies (i.e., screening, eligibility, included in systematic review, and, if applicable, included in the meta-analysis).

10 Describe method of data extraction from reports (e.g., piloted forms, independently, in duplicate) and any processes for obtaining and confirming data from investigators.

11 List and define all variables for which data were sought (e.g., PICOS, funding sources) and any assumptions and simplifications made.

12 Describe methods used for assessing risk of bias of individual studies (including specification of whether this was done at the study or outcome level), and how this information is to be used in any data synthesis.

13 State the principal summary measures (e.g., risk ratio, difference in means).

Background

Background

Methods

Methods

Methods

Methods

Methods

Methods

Methods

Methods

Methods

Methods

14 Describe the methods of handling data and combining results of studies, if done, including measures of consistency (e.g., $\mathrm{I}^{2}$ ) for each meta-analysis. 
Appendix 1. PRISMA checklis

\begin{tabular}{|c|c|c|c|}
\hline Section/topic & \# & Checklist item & $\begin{array}{l}\text { Reported } \\
\text { on page \# }\end{array}$ \\
\hline Risk of bias across studies & 15 & $\begin{array}{l}\text { Specify any assessment of risk of bias that may affect the cumulative evidence (e.g., publication } \\
\text { bias, selective reporting within studies). }\end{array}$ & Methods \\
\hline Additional analyses & 16 & $\begin{array}{l}\text { Describe methods of additional analyses (e.g., sensitivity or subgroup analyses, meta-regression), if } \\
\text { done, indicating which were pre-specified. }\end{array}$ & Methods \\
\hline \multicolumn{4}{|l|}{ Results } \\
\hline Study selection & 17 & $\begin{array}{l}\text { Give numbers of studies screened, assessed for eligibility, and included in the review, with reasons } \\
\text { for exclusions at each stage, ideally with a flow diagram. }\end{array}$ & Results \\
\hline Study characteristics & 18 & $\begin{array}{l}\text { For each study, present characteristics for which data were extracted (e.g., study size, PICOS, fol- } \\
\text { low-up period) and provide the citations. }\end{array}$ & Results \\
\hline Risk of bias within studies & 19 & $\begin{array}{l}\text { Present data on risk of bias of each study and, if available, any outcome level assessment (see item } \\
\text { 12). }\end{array}$ & Results \\
\hline Results of individual studies & 20 & $\begin{array}{l}\text { For all outcomes considered (benefits or harms), present, for each study: (a) simple summary data } \\
\text { for each intervention group (b) effect estimates and confidence intervals, ideally with a forest plot. }\end{array}$ & Results \\
\hline Synthesis of results & 21 & $\begin{array}{l}\text { Present results of each meta-analysis done, including confidence intervals and measures of con- } \\
\text { sistency. }\end{array}$ & Results \\
\hline Risk of bias across studies & 22 & Present results of any assessment of risk of bias across studies (see Item 15). & Results \\
\hline Additional analysis & 23 & $\begin{array}{l}\text { Give results of additional analyses, if done (e.g., sensitivity or subgroup analyses, meta-regression } \\
\text { [see Item 16]). }\end{array}$ & Results \\
\hline \multicolumn{4}{|l|}{ Discussion } \\
\hline Summary of evidence & 24 & $\begin{array}{l}\text { Summarize the main findings including the strength of evidence for each main outcome; consider } \\
\text { their relevance to key groups (e.g., healthcare providers, users, and policy makers). }\end{array}$ & Discussion \\
\hline Limitations & 25 & $\begin{array}{l}\text { Discuss limitations at study and outcome level (e.g., risk of bias), and at review-level (e.g., incom- } \\
\text { plete retrieval of identified research, reporting bias). }\end{array}$ & Discussion \\
\hline Conclusions & 26 & $\begin{array}{l}\text { Provide a general interpretation of the results in the context of other evidence, and implications for } \\
\text { future research. }\end{array}$ & Conclusion \\
\hline \multicolumn{4}{|c|}{ ( } \\
\hline Funding & 27 & $\begin{array}{l}\text { Describe sources of funding for the systematic review and other support (e.g., supply of data); role } \\
\text { of funders for the systematic review. }\end{array}$ & Funding \\
\hline
\end{tabular}

\begin{tabular}{|c|c|c|c|c|c|c|}
\hline \multirow[t]{2}{*}{ study name } & \multicolumn{5}{|c|}{ Statistics with study removed } & \multirow{2}{*}{$\begin{array}{l}\text { Event rate }(95 \% \mathrm{Cl}) \\
\text { with study removed }\end{array}$} \\
\hline & Point & $\begin{array}{c}\text { Lower } \\
\text { limit }\end{array}$ & $\begin{array}{c}\text { Upper } \\
\text { limit }\end{array}$ & z-value & $p$-value & \\
\hline Hajibagheri,2003 & 0.044 & 0.034 & 0.056 & -23.113 & 0.000 & \\
\hline Askarian, 2003 & & 0.035 & 0.057 & -22.886 & 0.000 & \\
\hline Askarian,2003 & 0.043 & 0.034 & 0.055 & $\begin{array}{l}-23.800 \\
-23000\end{array}$ & 0.000 & \\
\hline $\begin{array}{l}\text { Sadeghzadeh, } 2005 \\
\text { Soltani Arabshahi, 2005 }\end{array}$ & $\begin{array}{l}0.043 \\
0.044\end{array}$ & 0.033 & 0.055 & -23.266 & 0.000 & \\
\hline $\begin{array}{l}\text { Soltani Arabshahi,2005 } \\
\text { Rahbar,2005 }\end{array}$ & $\begin{array}{l}0.044 \\
0.044\end{array}$ & $\begin{array}{l}0.034 \\
0.034\end{array}-3$ & 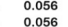 & $\begin{array}{l}-23.135 \\
-23.892\end{array}$ & $\begin{array}{l}0.000 \\
0.000\end{array}$ & \\
\hline Sadeghifard,2006 & 0.044 & 0.034 & 0.056 & -23.474 & 0.000 & \\
\hline Ekrami,2007 & 0.041 & 0.032 & 0.053 & -23.901 & 0.000 & 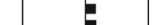 \\
\hline $\begin{array}{l}\text { Ghazvini,2008 } \\
\text { Lahsaeizadeh 2008 }\end{array}$ & $\begin{array}{l}0.045 \\
0.044\end{array}$ & $\begin{array}{l}0.035 \\
0.034\end{array}-3-3$ & $\begin{array}{l}0.058 \\
0.056\end{array}$ & $\begin{array}{r}-22.811 \\
-23.288\end{array}$ & $\begin{array}{l}0.000 \\
0.000\end{array}$ & E \\
\hline $\begin{array}{l}\text { Lahsaeizaded,he008 } \\
\text { Ghorban Alizadegan,2008 }\end{array}$ & $\begin{array}{l}0.044 \\
0.045\end{array}$ & $\begin{array}{l}0.034 \\
0.035\end{array}$ & $\begin{array}{l}0.056 \\
0.057\end{array}$ & $\begin{array}{l}-22.828 \\
-22.865\end{array}$ & $\begin{array}{l}0.000 \\
0.000\end{array}$ & 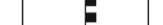 \\
\hline Hassanzadeh,2009 & 0.042 & $\begin{array}{l}0.033 \\
0.033\end{array}-1$ & 0.054 & $\begin{array}{l}-23.486 \\
-23.486\end{array}$ & 0.000 & e \\
\hline Asl,2009 & & & 0.056 & $\begin{array}{l}-23.078 \\
-2.078\end{array}$ & & \\
\hline Mohammadimehr,2009 & 0.042 & 0.033 & 0.054 & $\begin{array}{l}-23.493 \\
-2303\end{array}$ & 0.000 & E \\
\hline Amini, 2009 & 0.044 & 0.034 & 0.056 & -23.123 & 0.000 & e \\
\hline $\begin{array}{l}\text { Sohrabi,2009 } \\
\text { Darvishpour 2010 }\end{array}$ & $\begin{array}{l}0.047 \\
0.043\end{array}$ & $\begin{array}{l}0.036 \\
0.034\end{array}-3-10$ & $\begin{array}{l}0.060 \\
0.056\end{array}$ & $\begin{array}{l}-22.465 \\
-2.3 .170\end{array}$ & $\begin{array}{l}0.000 \\
0.000\end{array}$ & e \\
\hline $\begin{array}{l}\text { Darvishpour, 2010 } \\
\text { Aletayyeb, } 2010\end{array}$ & $\begin{array}{l}0.043 \\
0.045\end{array}-150$ & $\begin{array}{l}0.034 \\
0.035\end{array}$ & $\begin{array}{l}0.056 \\
0.057\end{array}$ & $\begin{array}{l}-23.170 \\
-22.876\end{array}$ & $\begin{array}{l}0.000 \\
0.000\end{array}$ & 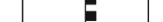 \\
\hline $\begin{array}{l}\text { Aletayyeb,2010 } \\
\text { Nadi,20111 }\end{array}$ & $\begin{array}{l}0.045 \\
0.044\end{array}$ & $\begin{array}{l}0.034 \\
0.034\end{array}-1$ & 0.056 & $\begin{array}{l}-23.2876 \\
-23.041\end{array}$ & $\begin{array}{l}0.000 \\
0.000\end{array}$ & E \\
\hline Tabatabaei,2011 & 0.044 & & 0.057 & -22.962 & 0.000 & \\
\hline Amini, 2011 & 0.044 & 0.034 & 0.056 & -23.123 & 0.000 & E \\
\hline $\begin{array}{l}\text { Ghorbani, } 2011 \\
\end{array}$ & $\begin{array}{l}0.044 \\
0.045\end{array}$ & 0.034 & 0.056 & -23.101 & 0.000 & e \\
\hline $\begin{array}{l}\text { Askarian, } 2011 \\
\text { Larypoor,2011 }\end{array}$ & $\begin{array}{l}0.045 \\
0.047\end{array}$ & $\begin{array}{l}0.035 \\
0.036\end{array}-15$ & $\begin{array}{l}0.058 \\
0.060\end{array}$ & $\begin{array}{l}-22.738 \\
-22.480\end{array}$ & $\begin{array}{l}0.000 \\
0.000\end{array}$ & E \\
\hline $\begin{array}{l}\text { Larypoor, 2011 } \\
\text { Masoumi As,2011 }\end{array}$ & $\begin{array}{l}0.047 \\
0.046\end{array}$ & $\begin{array}{l}0.036 \\
0.032\end{array}$ & $\begin{array}{l}0.060 \\
0.067\end{array}$ & $\begin{array}{l}-2.2480 \\
-15.125\end{array}$ & $\begin{array}{l}0.000 \\
0.000\end{array}$ & 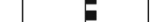 \\
\hline $\begin{array}{l}\text { Masoumin Al12,2017 } \\
\text { Mobaien,2012 }\end{array}$ & $\begin{array}{l}0.043 \\
0.043\end{array}$ & $\begin{array}{l}0.034 \\
0.034\end{array}$ & 0.056 & $\begin{array}{l}-15.125 \\
-23.231\end{array}$ & $\begin{array}{l}0.000 \\
0.000\end{array}$ & E \\
\hline Soltani, 2012 & 0.043 & 0.033 & 0.055 & $\begin{array}{lll}-23.678 \\
-2378\end{array}$ & 0.000 & 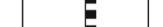 \\
\hline Alaghenbandan, 2012 & 0.043 & 0.034 & 0.055 & -23.626 & 0.000 & 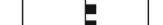 \\
\hline $\begin{array}{l}\text { Pourakbari,2012 } \\
\text { Barak,2012 }\end{array}$ & 0.045 & 0.035 & 0.058 & -22.811 & 0.000 & e \\
\hline $\begin{array}{l}\text { Barak,,2012 } \\
\text { Riahin,2012 }\end{array}$ & $\begin{array}{l}0.0046 \\
0.045\end{array}$ & $\begin{array}{l}0.035 \\
0.035\end{array}$ & $\begin{array}{l}0.059 \\
0.058\end{array}$ & $\begin{array}{l}-22.466 \\
-22.776\end{array}$ & $\begin{array}{l}0.000 \\
0.000\end{array}$ & 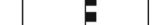 \\
\hline Askarian, 2012 & 0.044 & 0.034 & 0.056 & $\begin{array}{l}-23.471 \\
-23.46\end{array}$ & $\begin{array}{l}0.000 \\
0.000\end{array}$ & \\
\hline $\begin{array}{l}\text { Assar,2012 } \\
\text { Ass }\end{array}$ & 0.045 & 0.035 & 0.058 & -22.800 & 0.000 & a \\
\hline Zahraei,2012 & 0.047 & 0.034 & 0.065 & $\begin{array}{l}-17.190 \\
-2.000\end{array}$ & 0.000 & e \\
\hline Askarian, 2013 & 0.045 & 0.035 & 0.057 & -22.888 & 0.000 & \\
\hline $\begin{array}{l}\text { Abdoli Oskouie,2013 } \\
\text { Akbari. 2013 }\end{array}$ & $\begin{array}{l}0.046 \\
0.047\end{array}$ & 0.035 & 0.059 & -22.613 & 0.000 & e \\
\hline $\begin{array}{l}\text { Akbari,i,2013 } \\
\text { Masoumi Asl, 2013 }\end{array}$ & $\begin{array}{l}0.047 \\
0.046\end{array}$ & $\begin{array}{l}0.036 \\
0.036\end{array}$ & $\begin{array}{l}0.060 \\
0.059\end{array}$ & $\begin{array}{l}-22.460 \\
-22.374\end{array}$ & $\begin{array}{l}0.000 \\
0.000\end{array}$ & \\
\hline $\begin{array}{l}\text { Masoumi Ast, 2013 } \\
\text { Hamedi,2014 }\end{array}$ & $\begin{array}{l}0.046 \\
0.045\end{array}$ & $\begin{array}{l}0.035 \\
0.035\end{array}$ & $\begin{array}{l}0.058 \\
0.058\end{array}$ & $\begin{array}{l}-22.7314 \\
-22.731\end{array}$ & $\begin{array}{l}0.000 \\
0.000\end{array}$ & E \\
\hline Hoseini,2014 & 0.044 & 0.034 & 0.057 & -23.107 & 0.000 & E \\
\hline Behzadnia,2014 & 0.047 & 0.037 & 0.061 & -22.405 & 0.000 & 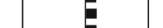 \\
\hline $\begin{array}{l}\text { Davoudi,2014 } \\
\text { Saktip } 2015\end{array}$ & 0.046 & 0.036 & 0.059 & -22.304 & 0.000 & \\
\hline $\begin{array}{l}\text { Shakib, } 2015 \\
\text { Basiri.2015 }\end{array}$ & 0.044 & $\begin{array}{l}0.034 \\
0.035\end{array}$ & 0.056 & $\begin{array}{r}-23.110 \\
-2929\end{array}$ & 0.000 & E \\
\hline $\begin{array}{l}\text { Basiri,2015 } \\
\text { Shojaei,2015 }\end{array}$ & $\begin{array}{l}0.044 \\
0.046\end{array}$ & $\begin{array}{l}0.035 \\
0.036\end{array}$ & $\begin{array}{l}0.057 \\
0.059\end{array}$ & $\begin{array}{l}-22.2929 \\
-22.533\end{array}$ & $\begin{array}{l}0.000 \\
0.000\end{array}$ & E \\
\hline $\begin{array}{l}\text { Shoje,l,2015 } \\
\text { Lavakhamseh,2015 }\end{array}$ & $\begin{array}{l}0.046 \\
0.046\end{array}$ & $\begin{array}{l}0.036 \\
0.036\end{array}$ & $\begin{array}{l}0.059 \\
0.059\end{array}$ & $\begin{array}{l}-22.2333 \\
-22.444\end{array}$ & 0.000 & 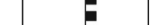 \\
\hline Salmanzadeh,2015 & 0.046 & 0.036 & 0.059 & -22.543 & 0.000 & 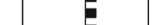 \\
\hline Bijari,2015 & 0.046 & 0.036 & 0.059 & -22.427 & 0.000 & E \\
\hline $\begin{array}{l}\text { Tabatabaei, } 2015 \\
\text { Parrishpor }\end{array}$ & 0.046 & 0.036 & 0.059 & -22.534 & 0.000 & 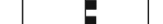 \\
\hline \multirow{3}{*}{$\begin{array}{l}\text { Kazemian,2016 } \\
\text { Falahi,2017 }\end{array}$} & $\begin{array}{l}0.044 \\
0.045\end{array}$ & $\begin{array}{l}0.034 \\
0.035\end{array}$ & 0.057 & $\begin{array}{l}-23.013 \\
-23.35\end{array}$ & 0.000 & E \\
\hline & $\begin{array}{l}0.045 \\
0.046\end{array}$ & $\begin{array}{l}0.035 \\
0.036\end{array}$ & $\begin{array}{l}0.057 \\
0.059\end{array}$ & $\begin{array}{l}-23.135 \\
-22.422\end{array}$ & $\begin{array}{l}0.000 \\
0.000\end{array}$ & 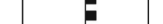 \\
\hline & 0.045 & 0.035 & 0.057 & -23.074 & 0.000 & \\
\hline
\end{tabular}


Prevalence of nosocomial infections in Iran

Appendix 3. Result of cumulative meta-analysis based on year of publication

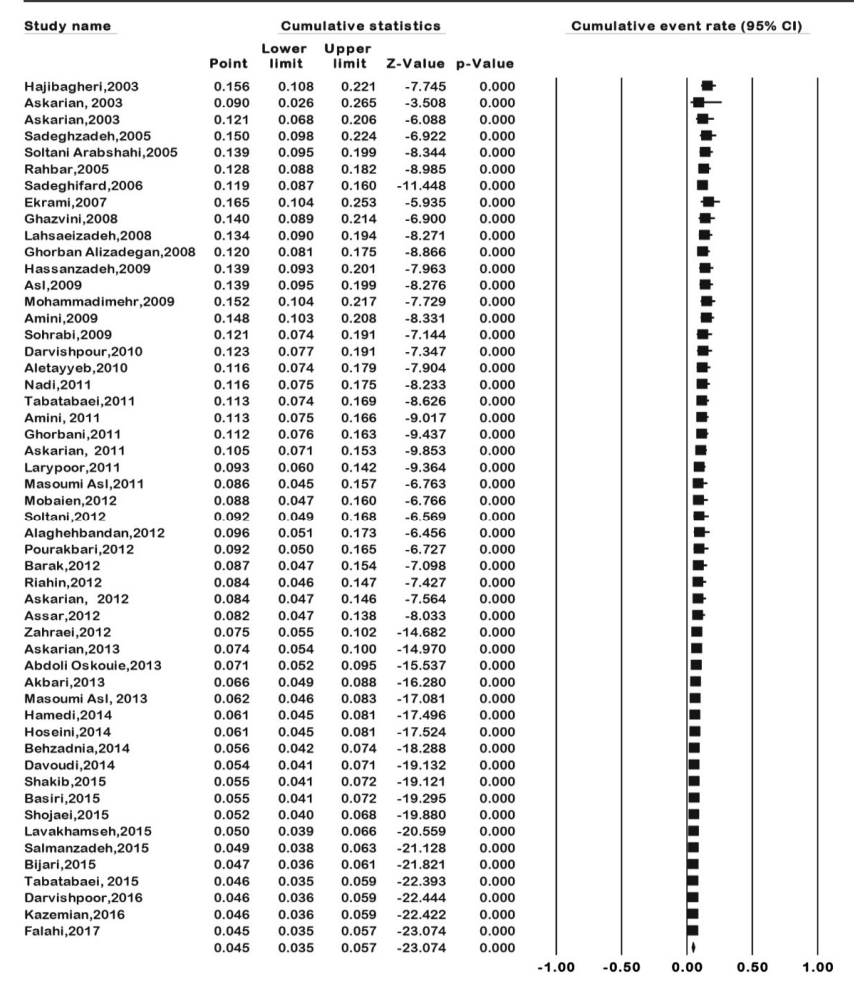

